\title{
P254: The hospital-acquired infections in regional hospital in Niger Tahoua
}

\author{
H Djibo $^{1 *}$, M Kamay $^{2}$, A Baden $^{3}$ \\ From 2nd International Conference on Prevention and Infection Control (ICPIC 2013) \\ Geneva, Switzerland. 25-28 June 2013
}

\section{Introduction}

Nosocomial infections recur periodically on the front of the stage and are nowadays recognized as major public health problems due to their frequency, severity and cost. Programs have been developed to slow the progression of nosocomial infections.

Despite all these efforts, nosocomial infections remain a persistent problem. In Africa, as in most developing countries, there are no national data on the prevalence of nosocomial infections.

\section{Objectives}

To contribute to improving the quality of care and professional practices has an impact on the risk of infection.

\section{Methods}

Prospective cross-sectional study made at the Centre Hospitalier Régional (CHR) Tahoua over a period of four months (June to September 2008) using a questionnaire and review of patient records to identify patients having contracted a nosocomial infection.

It involved patients of both sexes and all ages, and in some cases their carers and health workers identified in the various departments of Tahoua CHR located $600 \mathrm{~km}$ from Niamey.

\section{Results}

Patients older than 56 years have contracted the largest number of nosocomial infections with a rate of $30.89 \%$ of cases. The departments of female Medicine and Surgery recorded the highest rates of nosocomial infections with respectively $26.7 \%$ and $27.74 \%$.

More than nine out of ten patients with nosocomial infections (92.67\%) did not have an invasive device. The

${ }^{1}$ Department of Public Health, Faculty of Health Sciences, University of Niamey, Niger

Full list of author information is available at the end of the article average length of stay due to nosocomial infection is 4 days.

\section{Conclusion}

Nosocomial infection is a constant concern in hospital practices of our country. Morbidity, mortality and cost caused by these infections justify the establishment of structures for monitoring, prevention and treatment.

\section{Competing interests}

None declared.

\section{Author details}

${ }^{1}$ Department of Public Health, Faculty of Health Sciences, University of Niamey, Niger. ${ }^{2}$ Health Sector Control Unit against STI / HIV / AIDS, Ministry of Public Health, Niger. ${ }^{3}$ Niamey National Hospital, Niamey, Niger.

Published: 20 June 2013

doi:10.1186/2047-2994-2-S1-P254

Cite this article as: Djibo et al:: P254: The hospital-acquired infections in regional hospital in Niger Tahoua. Antimicrobial Resistance and Infection Control 2013 2(Suppl 1):P254

Submit your next manuscript to BioMed Central and take full advantage of:

- Convenient online submission

- Thorough peer review

- No space constraints or color figure charges

- Immediate publication on acceptance

- Inclusion in PubMed, CAS, Scopus and Google Scholar

- Research which is freely available for redistribution

\section{Biomed Central}

